\title{
Do We Really Care About Biodiversity?
}

\section{David Pearce}

Published online: 2 October 2007

(C) Springer Science+Business Media B.V. 2007

\section{Erratum to: Environ Resource Econ (2007) DOI 10.1007/s10640-007-9118-3}

The copyright line to the original of this article should have been (C) Cambridge University Press.

Springer would like to apologize for this oversight.

The online version of the original article can be found under doi:10.1007/s10640-007-9118-3.

D. Pearce $(\varangle)$

University College London, London, UK 